\title{
ORGANIC MATTER REDUCES COPPER TOXICITY FOR THE EARTHWORM Eisenia fetida IN SOILS FROM MINING AREAS IN CENTRAL CHILE
}

\author{
Gonzalo Ávila, Hernán Gaete², Sébastien Sauvé ${ }^{3}$, and Alexander Neaman ${ }^{14^{*}}$
}

\begin{abstract}
The Aconcagua River basin (Central Chile) is one of the most important agricultural areas in the country. However, several copper $(\mathrm{Cu})$ mining operations are located in the basin. The objective of the study was to determine $\mathrm{Cu}$ toxicity for the earthworm Eisenia fetida (Savigny 1826) in the agricultural soils of the basin. We determined the production of cocoons and juveniles of earthworms in the studied soils. The soils differed in the concentrations of organic matter (OM, range 2-6\%), pH (range 7.3-8.3), texture (from loamy sand to clay loam), and total $\mathrm{Cu}$ concentrations (range 230-960 $\mathrm{mg} \mathrm{kg}^{-1}$ ). Concentrations of $\mathrm{Cu}$ and $\mathrm{OM}$ in the soils were the variables that determined the earthworms' biological response. In contrast, $\mathrm{pH}$ and texture did not affect this response. Cocoon and juvenile production decreased considerably in soils with elevated $\mathrm{Cu}$ concentrations ( $\left.>500 \mathrm{mg} \mathrm{kg}^{-1}\right)$, regardless of OM concentrations. Cocoon production decreased in the soils with $\mathrm{Cu}$ concentrations below $500 \mathrm{mg} \mathrm{kg}^{-1}$ when $\mathrm{OM}$ concentrations were below 3.5\%. In contrast, cocoon production did not vary when OM concentrations were above $3.5 \%$. The same effect of OM was observed on juvenile production. In this case, the threshold for OM concentration was $2.5 \%$. It was concluded that it is important to consider OM concentrations in order to predict the biological response of earthworms in these soils.
\end{abstract}

Key words: Eisenia fetida, Aconcagua River, ecological risk assessment, $\mathrm{Cu}$ mining, trace elements.

\section{INTRODUCTION}

Copper $(\mathrm{Cu})$ mining is the most important economic activity in Chile. However, the environmental problems historically associated with copper mining are widely known, particularly in relation to the contamination of agricultural soils by trace elements such as $\mathrm{Cu}$ (González et al., 2008; De Gregori et al., 2003). Although $\mathrm{Cu}$ is an essential element for all organisms, it becomes toxic at high concentrations (Sauvé et al., 1998).

The Aconcagua River basin in Central Chile is one of the most important agricultural areas in the country. On the other hand, several copper mining industries are located in the agricultural areas of the basin. There is little information available about the toxicity of copper for organisms and crops in agricultural soils of Chile.

${ }^{1}$ Pontificia Universidad Católica de Valparaíso, Facultad de Agronomía, Casilla 4-D, Quillota, Chile.

"Corresponding author (alexander.neaman@ucv.cl).

${ }^{2}$ Universidad de Valparaíso, Facultad de Ciencias, Av. Gran Bretaña 1111, Valparaíso, Chile.

${ }^{3}$ Université de Montréal, Département de Chimie, CP 6128 Centreville, Montréal, QC, H3C 3J7, Canada.

${ }^{4}$ Centro Regional de Estudios en Alimentos Saludables (CREAS), Blanco 1623, Of. 1402, Valparaíso, Chile.

Received: 11 June 2008.

Accepted: 06 July 2008.
Knowing the total concentration of a trace element in a soil is not sufficient to predict the potential ecological risk that it represents (Sauvé et al., 1998). Ecological risk is more related to the bioavailability of the element that, in turn, is related to the chemical form in which it is found in the soil. The National Research Council (NRC, 2003) defines bioavailability as the fraction of the total element that is available to the receptor organism.

Chile currently does not have any legislation on the maximum acceptable concentrations of toxic elements in soils. In the opinion of the authors based on what is outlined above, any future legislation should distinguish between soils where trace elements are present but do not represent a risk from those that, at similar concentration of trace elements, do represent significant ecological risks.

An approximation that can be used to solve this problem is carrying out toxicity bioassays with soil macroorganisms. Standardized bioassays that determine the acute and chronic toxicity with earthworm E. fetida are particularly suitable (OECD, 2000). E. fetida is considered representative of soil macrofauna and of earthworms in particular (OECD, 2000). The objective of the present study was to determine the toxicity of trace elements for earthworms in agricultural soils from mining areas in Central Chile. 


\section{MATERIALS AND METHODS}

\section{Site selection and soil sampling}

The selection of sampling sites was based on the results of a previous study on the distribution of copper in agricultural soils in the Aconcagua River basin (R. Aguilar, unpublished results). This study revealed that the Catemu Creek sub-basin has the largest surface area of soils with high concentrations of $\mathrm{Cu}$.

With the objective of obtaining samples with a wide range of total $\mathrm{Cu}$ concentration, 13 localities of the Catemu Creek sub-basin were sampled (Table 1). In each locality, $10 \mathrm{~kg}$ of soil were obtained, from a soil depth of 0 to 20 $\mathrm{cm}$, following the removal of the existing vegetation. The soils were then taken to the laboratory of the Faculty of Agriculture, Pontifical Catholic University of Valparaiso, where they were dried at $60{ }^{\circ} \mathrm{C}$ for 2 days. Then, the soils were disaggregated in a porcelain mortar and sieved to 2 $\mathrm{mm}$.

\section{Physical-chemical analysis of the soils}

The total concentrations of $\mathrm{Cu}$, lead $(\mathrm{Pb})$ and zinc $(\mathrm{Zn})$ were determined by atomic absorption spectrophotometry (GBC, model 902, Dandenong, Victoria, Australia) following acid digestion of the soils with a mixture of fluorhydric and perchloric acids (Maxwell, 1968). The determination of total arsenic (As) in the soils was carried out using neutron activation analysis. To ensure the quality of the results, reference samples were analyzed. For all the cases, the percentage of difference between the obtained values versus the certified values did not exceed $10 \%$.
The soil texture was determined using the simplified hydrometer method according to Sheldrick and Wang (1993). The concentration of organic matter (OM) was determined according to Sadzawka et al. (2006). Electrical conductivity (EC) and $\mathrm{pH}$ were determined in saturated paste extracts (Sadzawka et al., 2006). Soluble $\mathrm{Cu}$ concentration and activity of free $\mathrm{Cu}^{2+}$ ion $\left(\mathrm{pCu}^{2+}\right)$ were determined in the same extract by atomic absorption spectrophotometry and by ion selective electrode (Rachou et al., 2007a), respectively.

\section{Bioassays of toxicity}

To determine chronic toxicity, bioassays with the earthworm Eisenia fetida were carried out using the protocols of the OECD (2000). Specifically, $500 \mathrm{~g}$ of soil was adjusted to a humidity of $40 \% \mathrm{w} / \mathrm{w}$ and placed in experimental glass containers of $750 \mathrm{~mL}$. Ten adult earthworms (with visible clitellum) were incubated in each container. Earthworms were previously washed with distilled water, blotted dry and weighed. Five grams of cow manure were moistened with $5 \mathrm{~mL}$ of distilled water and added to each container. Eight replicates were made with each soil. The design was randomized. After 4 weeks of exposure, the weight, adult survival and number of cocoons were determined. Then, the cocoons were incubated in the same soil for additional 4 weeks and the number of juveniles was determined. Room temperature was maintained within the range of 22 to $24{ }^{\circ} \mathrm{C}$, with illumination of 200 lux and a photoperiod of $12 \mathrm{~h}$ of light and $12 \mathrm{~h}$ of darkness. Moisture was maintained by the application of $40 \mathrm{~mL}$ of distilled water once a week. Soil 41 was considered as a control because of the lowest concentrations of $\mathrm{Cu}$ among the studied soils (Table 1).

Table 1. Physico-chemical characteristics of the studied soils.

\begin{tabular}{|c|c|c|c|c|c|c|c|c|c|c|}
\hline Soil & Texture & OM & $\mathrm{Cu}$ & $\mathbf{P b}$ & $\mathrm{Zn}$ & As & $\mathrm{CE}$ & pH & $\mathrm{pCu}^{2+}$ & $\mathbf{C u}$ \\
\hline & & $\%$ & 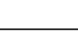 & $-\mathrm{m}$ & -1 & 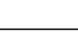 & $\mathrm{dS} \mathrm{m}^{-1}$ & & & $\mathrm{mg} \mathrm{L}^{-1}$ \\
\hline 18 & Sandy loam & 5.2 & 959 & 542 & 923 & 44 & 2.3 & 7.3 & 7.3 & 2.70 \\
\hline 27 & Sandy loam & 3.5 & 847 & 81 & 209 & 19 & 2.4 & 7.9 & 7.9 & 0.74 \\
\hline 28 & Loam & 2.2 & 382 & 81 & 244 & 17 & 1.3 & 8.0 & 8.0 & 0.28 \\
\hline 29 & Loam & 4.0 & 431 & 30 & 156 & 21 & 0.8 & 8.3 & 8.3 & 0.67 \\
\hline 30 & Clay loam & 5.2 & 426 & 46 & 135 & 30 & 2.2 & 7.6 & 7.6 & 0.29 \\
\hline 31 & Loam & 5.3 & 354 & 36 & 117 & 24 & 2.9 & 8.1 & 8.1 & 0.56 \\
\hline 37 & Loamy sand & 2.0 & 354 & 36 & 97 & 30 & 2.6 & 7.9 & 7.9 & 0.38 \\
\hline 38 & Loam & 3.5 & 434 & 40 & 117 & 28 & 2.5 & 7.9 & 7.9 & 0.22 \\
\hline 41 & Loam & 6.0 & 226 & 36 & 148 & 29 & 4.8 & 7.8 & 7.8 & 0.60 \\
\hline 49 & Loam & 5.6 & 707 & 47 & 134 & 37 & 4.1 & 8.0 & 8.0 & 0.83 \\
\hline 50 & Clay loam & 4.0 & 650 & 63 & 146 & 45 & 1.5 & 8.2 & 8.2 & 0.46 \\
\hline 52 & Loam & 2.8 & 597 & 47 & 133 & 36 & 2.1 & 8.2 & 8.2 & 0.48 \\
\hline
\end{tabular}

OM: organic matter. $\mathrm{CE}$ : electrical conductivity. $\mathrm{pCu}^{2+}:-\log$ (activity of the free $\mathrm{Cu}^{2+}$ ion). 


\section{Statistical analysis}

Using the Dunnett test, comparisons between the responses of the earthworms in the studied soils and the control soil have been made. Simple and multiple regressions were made between the responses of the earthworms and the physico-chemical characteristics of the soils. Also, simple regressions were made between the concentrations of $\mathrm{Pb}, \mathrm{Zn}$ or As and those of $\mathrm{Cu}$. We used the Minitab 3.1 and Excel 2003 for statistical analysis.

\section{RESULTS AND DISCUSSION}

\section{Soil characterization}

The studied soils were different in OM concentrations (range of $2-6 \%$ ), EC (range of $0.8-4.8 \mathrm{dS} \mathrm{m}^{-1}$ ), $\mathrm{pH}$ (range of 7.3 - 8.3) and texture (from loamy sand to clay loam). The soils presented a wide range of total $\mathrm{Cu}$ concentration (from 230 to $960 \mathrm{mg} \mathrm{kg}^{-1}$ ) (Table 1). These high $\mathrm{Cu}$ concentrations are mainly due to mining activities, while application of copper-based products in agriculture represents a minor source (R. Aguilar, unpublished results). Simple regressions revealed that the relations between the concentrations of $\mathrm{Pb}, \mathrm{Zn}$ and As (Table 1) versus those of $\mathrm{Cu}$ were not significant $(\mathrm{P}>$ $0.05)$.

\section{Validity of the control soil}

The OECD (2000) established the following criteria for validity of the control soil: (1) each repetition (10 adult earthworms) should produce at least 30 juveniles at the end of the bioassay, (2) the variation coefficient in the reproduction parameters must be less than $30 \%$, and (3) adult mortality must be less than $10 \%$. Additional to this, Spurgeon et al. (2003) propose that weight loss should be less than $15 \%$. These four criteria were satisfied in the control soil (Table 2).

\section{Survival and weight loss}

In all the soils used, the earthworm survival was higher than $98 \%$ and weight loss did not exceed $20 \%$ (Table 2). The data of survival presented a very narrow range (98$100 \%$ ) and, thus, it was not possible to carry out regressions with the physico-chemical characteristics of the soils. On the other hand, the physico-chemical characteristics of the soils did not explain weight variation. As shown below, the survival and weight loss are variables that less sensitive to $\mathrm{Cu}$ toxicity, in comparison to the reproduction variables.

\section{Identification of the variables that affected reproduction}

Bioassays with earthworms have been widely used to determine the toxicity of trace elements in soils (Spurgeon et al., 2003). However, the technique has been criticized for not adequately representing real environmental conditions and, consequently, not being relevant from an environmental point of view (Davies et al., 2003). The criticism is based on the fact that the OECD (2000) proposes the use of artificial soils (composed of peat, clay, and sand) enriched with solutions of metals at increasing concentrations. In fact, it has been observed that the toxicity of trace elements for earthworms is considerably higher in artificially-contaminated soil media than in field-collected soils. This is explained by a greater bioavailability of trace

Table 2. Results of chronic toxicity bioassays (OECD, 2000). Soil 41 was considered as a control (C).

\begin{tabular}{|c|c|c|c|c|c|}
\hline Soil & Survival & Weight loss & Number of cocoons & Number of juveniles & $\mathrm{Cu}$ in earthworms \\
\hline & 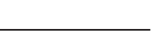 & - & & & $\mathrm{mg} \mathrm{kg}^{-1}$ \\
\hline $41(\mathrm{C})$ & $100 \pm 0$ & $(-) 14 \pm 3.8$ & $28 \pm 3.2$ & $54 \pm 4.4$ & $23 \pm 0.8$ \\
\hline 18 & $100 \pm 0$ & $(-) 4 \pm 8.9$ & $11 \pm 6.5^{*}$ & $19 \pm 17^{*}$ & $61 \pm 31^{*}$ \\
\hline 27 & $99 \pm 3.5$ & (-) $8 \pm 5.4$ & $6 \pm 4.0^{*}$ & $14 \pm 9.0^{*}$ & $64 \pm 4.4^{*}$ \\
\hline 28 & $100 \pm 0$ & $(-) 10 \pm 9.7$ & $9 \pm 5.6^{*}$ & $8 \pm 9.8^{*}$ & $37 \pm 0.4$ \\
\hline 29 & $100 \pm 0$ & $(-) 15 \pm 3.5$ & $26 \pm 5.2$ & $50 \pm 12$ & $37 \pm 3.8$ \\
\hline 30 & $98 \pm 4.6$ & $(-) 8 \pm 5.8$ & $18 \pm 3.0^{*}$ & $36 \pm 4.4^{*}$ & $39 \pm 1.9$ \\
\hline 31 & $100 \pm 0$ & (+) $1 \pm 3.9^{*}$ & $20 \pm 4.1^{*}$ & $41 \pm 5.7$ & $51 \pm 4.5^{*}$ \\
\hline 37 & $100 \pm 0$ & $(-) 8 \pm 4.5$ & $15 \pm 6.3^{*}$ & $23 \pm 7.9^{*}$ & $41 \pm 2.9$ \\
\hline 38 & $99 \pm 3.5$ & (+) $2 \pm 6.8^{*}$ & $15 \pm 5.5^{*}$ & $41 \pm 17$ & $59 \pm 3.5^{*}$ \\
\hline 49 & $100 \pm 0$ & $(-) 19 \pm 8.0$ & $9 \pm 5.1^{*}$ & $24 \pm 12^{*}$ & $46 \pm 0.6$ \\
\hline 50 & $98 \pm 4.6$ & $(-) 6 \pm 6.8$ & $4 \pm 3.1^{*}$ & $14 \pm 7.8^{*}$ & $46 \pm 0.6$ \\
\hline 52 & $100 \pm 0$ & $(+) 2 \pm 12 *$ & $5 \pm 4.3^{*}$ & $13 \pm 6.8^{*}$ & $37 \pm 27$ \\
\hline
\end{tabular}

* Significantly different from the control according to the Dunnett test $(\mathrm{P}<0.05)$.

\pm : Standard deviation. $(-)=$ Weight loss. $(+)=$ Weight increase. 
elements in artificially-contaminated soils in comparison to those collected in the field (Spurgeon and Hopkin, 1995). As a result, recent studies highlight the importance of using field-collected soils to evaluate ecological risk of trace elements present in the soil (Nahmani et al., 2007a; 2007b).

On the other hand, the use of field-collected soils presents several difficulties. First, in areas near copper mining activities, soils have high concentrations of several trace elements $(\mathrm{Cu}, \mathrm{Pb}, \mathrm{Zn}, \mathrm{Cd}$ and $\mathrm{As}$, among others; De Gregori et al., 2003; Ginocchio et al., 2004). In this case, it could be difficult to distinguish between the effects of different trace elements on the response of the earthworms. Second, agricultural soils can contain other types of chemical compounds, such as pesticides and/or fungicides, which can affect the response of the earthworms (Slimak, 1997). Finally, the intrinsic physicochemical characteristics of the soil, such as $\mathrm{pH}$, texture and OM content, among others, also affect the degree of toxicity of the trace elements present in the soil (Kennette et al., 2002, Nahmani et al., 2007a).

In the present study, the variables that affected earthworm reproduction were identified using simple and multiple regressions between earthworm responses and the physico-chemical characteristics of the soils. The regressions ruled out any evident effects of $\mathrm{Pb}, \mathrm{Zn}$, and $\mathrm{As}$ on the response of earthworms. The simple and multiple regressions between earthworm reproduction and the physico-chemical characteristics of the soils indicated that $\mathrm{pH}$, texture, $\mathrm{EC}$, and soluble $\mathrm{Cu}$ concentration did not affect the response of the earthworms. On the other hand, a significant regression was observed between $\mathrm{pCu}^{2+}$ and earthworm reproduction (Table 3). The effect of free $\mathrm{Cu}^{2+}$ ion will be discussed in detail below.

The best prediction of the earthworm response was obtained by considering total $\mathrm{Cu}$ concentrations together with OM (Table 3). The regression coefficients increased upon considering both variables together, in comparison to total $\mathrm{Cu}$ alone. This effect of $\mathrm{OM}$ on $\mathrm{Cu}$ toxicity will be discussed in detail below.
Thus, the effects observed on earthworm reproduction are mainly due to $\mathrm{Cu}$ and $\mathrm{OM}$, explaining about $70 \%$ of the variance (Table 3). Nevertheless, the studied soils could contain other undetermined compounds (for example, pesticides and/or fungicides) that have affected earthworm reproduction.

\section{Effect of OM on the toxicity of copper}

The earthworm E. fetida lives in environments rich in OM (OECD, 2000). Despite this, the regressions between OM concentrations and earthworm reproduction were not significant. This suggests that $\mathrm{OM}$ does not have a direct effect on the reproduction parameters. This concurs with Spurgeon and Hopkin (1999) who indicated that E. fetida was not able to obtain sufficient nutrients from mineral soils (with $\mathrm{OM}<20 \%$ ), requiring the addition of food to the soils used in the bioassays.

The multiple regressions show that $\mathrm{OM}$ promotes cocoon and juvenile production, while total $\mathrm{Cu}$ decreases earthworm reproduction. Consequently, it is necessary to consider OM content to predict the biological responses of earthworms in soils contaminated with trace elements.

The soils with more than $50 \%$ of inhibition in the production of cocoons or juveniles are considered as toxic for earthworms (Hund-Rinke and Wiechering, 2001; HundRinke et al., 2005). The soils with total $\mathrm{Cu}$ concentrations higher than $500 \mathrm{mg} \mathrm{kg}^{-1}$ were toxic, independent of the OM concentrations (Figure 1). In contrast, in the soils with total $\mathrm{Cu}$ concentrations below $500 \mathrm{mg} \mathrm{kg}^{-1}$, OM concentrations determined Cu toxicity. In the case of cocoon production, the soils with total $\mathrm{Cu}$ concentrations below $500 \mathrm{mg} \mathrm{kg}^{-1}$ were toxic when OM concentrations were lower than 3.5\%. The opposite was observed in the case of OM concentrations above $3.5 \%$ (Figure 1). In the case of juvenile production in soils with total $\mathrm{Cu}$ concentrations below $500 \mathrm{mg} \mathrm{kg}^{-1}$, the critical threshold for OM concentration was about $2.5 \%$ (Figure 2).

The combined effect of total $\mathrm{Cu}$ and $\mathrm{OM}$ on the response of earthworms is due to the control that these two variables exert on the activity of the $\mathrm{Cu}^{2+}$ ion that

Table 3. Regressions between the number of cocoons/juveniles and soil copper concentrations.

\begin{tabular}{|c|c|c|c|c|c|}
\hline Production of cocoons & $\mathbf{R}^{2}$ & $\mathbf{P}$ & Production of juveniles & $\mathbf{R}^{2}$ & $\mathbf{P}$ \\
\hline $\mathrm{PC}=26+0.02 \mathrm{CuT}$ & 0.44 & 0.02 & $\mathrm{PJ}=50-0.04 \mathrm{CuT}$ & 0.34 & 0.05 \\
\hline $\mathrm{PC}=15-1.6 \mathrm{CuS}$ & 0.21 & 0.12 & $\mathrm{PJ}=30-3 \mathrm{CuS}$ & 0.23 & 0.10 \\
\hline $\begin{array}{r}\mathrm{PC}=16-0.03 \mathrm{CuT}+2.8 \mathrm{OM} \\
(0.005) \quad(0.03)\end{array}$ & 0.68 & 0.01 & $\begin{array}{r}\mathrm{PJ}=24-0.05 \mathrm{CuT}+6.8 \mathrm{OM} \\
(0.01) \quad(0.01)\end{array}$ & 0.68 & 0.01 \\
\hline $\mathrm{PC}=-69+8.5 \mathrm{pCu}^{2+}$ & 0.43 & 0.02 & $\mathrm{PJ}=-118+15 \mathrm{pCu}^{2+}$ & 0.35 & 0.04 \\
\hline
\end{tabular}

PC: Production of cocoons. PJ: production of juveniles. OM: organic matter (\%). CuT: total copper $\left(\mathrm{mg} \mathrm{kg}^{-1}\right)$. CuS: soluble copper $\left(\mathrm{mg} \mathrm{L}^{-1}\right)$. $\mathrm{pCu}^{2+}$ : - $\log$ (activity of the free $\mathrm{Cu}^{2+}$ ion). $\mathrm{R}^{2}$ : regression coefficient. $\mathrm{P}$ : probability. Number in parenthesis indicates the $\mathrm{P}$ value of the variable in multiple regressions. 


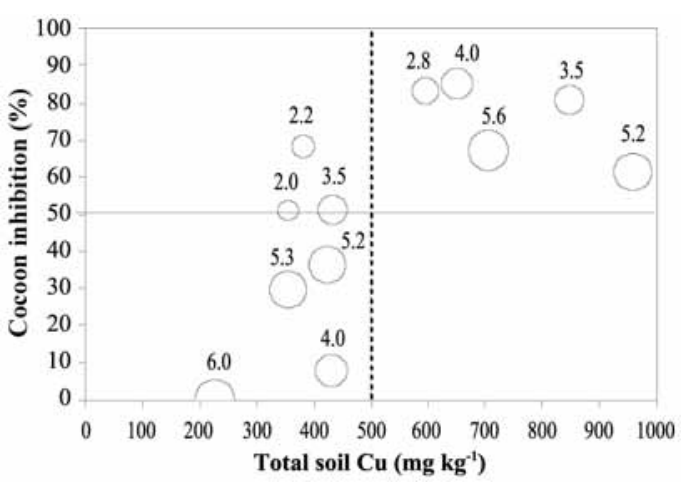

Figure 1. Effect of total copper and organic matter on cocoon production. The size of the circles and the values represent the percentage of organic matter in each soil.

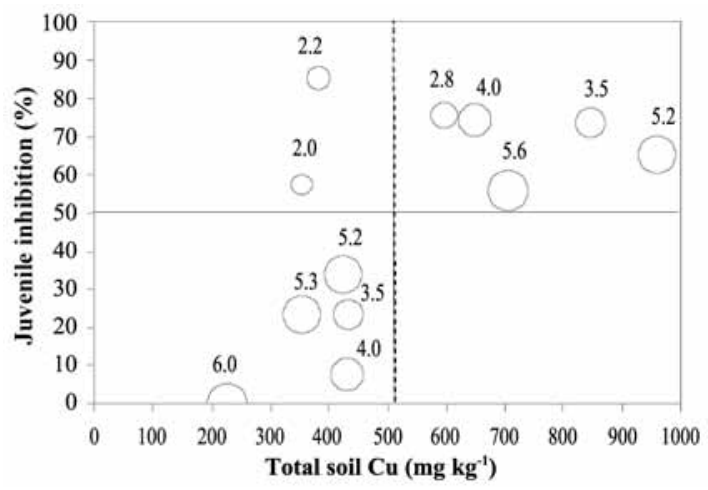

Figure 2. Effect of total copper and organic matter on juvenile production. The size of the circles and the values represent the percentage of organic matter in each soil.

is considered as the bioavailable form of $\mathrm{Cu}$ in the soil (Sauvé et al., 1998; Thakali et al., 2006). McBride et al. (1997) and Sauvé et al. (1997) proposed an empirical equation that describes the effect of the physico-chemical properties of the soil on the activity of the $\mathrm{Cu}^{2+}$ ion: $\mathrm{pCu}^{2+}$ $=\mathrm{a}+\mathrm{b} \mathrm{pH}+\mathrm{c} \log \mathrm{CuT}+\mathrm{d} \log \mathrm{OM}$. In agreement with this postulate, in the present study, the activity of the $\mathrm{Cu}^{2+}$ ion in the saturated paste extracts was controlled by the concentrations of $\mathrm{OM}$ and total $\mathrm{Cu}$ (Table 4). In turn, $\mathrm{pH}$ did not affect $\mathrm{pCu}^{2+}$, probably because of the narrow $\mathrm{pH}$ range in the studied soils ( $\mathrm{pH}$ of 7.3 to 8.3).

Also, the effect of $\mathrm{OM}$ in reducing $\mathrm{Cu}$ toxicity for earthworms is probably due to a change in the mobilization of copper from the solid phase to the soil solution. According to Rachou et al. (2007b), the kinetics of the mobilization of the elements from the solid phase to the soil solution decreases with increasing concentration of OM. Thus, the decrease in the flow of $\mathrm{Cu}$ from the solid phase to the soil solution can, in turn, reduce its toxicity for the earthworms.

\section{Effect of different forms of copper on reproduction}

The bioavailability of a trace element can be estimated through a chemical analysis that extracts a fraction of the element. Diverse extractants were proposed to simulate the bioavailability of trace elements for plants and soil organisms. It is often considered that the bioavailable fraction of a trace element corresponds to its soluble form (Posthuma et al., 1997; Kabata-Pendias, 2004). Nevertheless, the regressions between earthworm reproduction and $\mathrm{Cu}$ concentrations in the saturated paste extract, corresponding to the soluble form of $\mathrm{Cu}$ (Table 3), indicated that this form of the element did not affect the earthworms' reproduction.

On the other hand, the $\mathrm{Cu}^{2+}$ ion is the bioavailable form of $\mathrm{Cu}$ both in soil and water (Thakali et al., 2006). The activity of the $\mathrm{Cu}^{2+}$ ion is often considered to be the best variable to predict $\mathrm{Cu}$ toxicity for plants, organisms and microbial processes in the soil (Sauvé et al., 1998). In accordance with these postulates, in the present study, the regressions between $\mathrm{pCu}^{2+}$ in saturated paste extract and earthworms' reproduction were significant (Table 3).

\section{Bioaccumulation of copper}

Earthworms can actively excrete $\mathrm{Cu}$ assimilated in their tissues (Spurgeon and Hopkin, 1999). This implies extra energy costs, generating a reduction in energy available for growth and development. This, in turn, affects sexual maturity and production of cocoons and juveniles (Spurgeon and Hopkin, 1996). Likewise, the efficiency of excretion probably decreases with increasing concentrations of $\mathrm{Cu}$, resulting in increased bioaccumulation (i.e., the concentration of assimilated $\mathrm{Cu}$ in earthworm tissue) in the soils with higher $\mathrm{Cu}$ concentrations (Svendsen and Weeks, 1997; ScottFordsmand et al., 2000).

In the present study, the concentrations of total $\mathrm{Cu}$ in the soil explained $53 \%$ of the variance $(\mathrm{P}=0.001)$ in the bioaccumulation of $\mathrm{Cu}$. In contrast, other soil properties like $\mathrm{pH}, \mathrm{OM}$ and other forms of $\mathrm{Cu}$ (soluble or free) did

Table 4. Effect of total copper, organic matter and $\mathrm{pH}$ on $\mathrm{pCu}^{2+}$.

\begin{tabular}{|c|c|c|}
\hline & $\overline{\mathbf{R}^{2}}$ & $\mathbf{P}$ \\
\hline $\mathrm{pCu}^{2+}=15-2 \log \mathrm{CuT}$ & 0.34 & 0.04 \\
\hline $\begin{array}{r}\mathrm{pCu}^{2+}=14-2 \log \mathrm{CuT}+1.9 \log \mathrm{OM} \\
(0.018)\end{array}$ & 0.59 & 0.01 \\
\hline $\begin{array}{rr}\mathrm{pCu}^{2+}=7-2 \log \mathrm{CuT}+2 \log \mathrm{OM}+0.8 \mathrm{pH} \\
(0.020) & (0.014)\end{array}$ & 0.72 & 0.01 \\
\hline
\end{tabular}

CuT: total copper $\left(\mathrm{mg} \mathrm{kg}^{-1}\right)$. OM: organic matter $(\%) \cdot \mathrm{pCu}^{2+}:-\log$ (activity of the free $\mathrm{Cu}^{2+}$ ion).

$\mathrm{R}^{2}$ : regression coefficient. P: probability. Numbers in parenthesis indicate the $\mathrm{P}$ value of the variable in multiple regressions. 
not affect its bioaccumulation. The concentrations of $\mathrm{Cu}$ in the tissues were in the range of 23 to $64 \mathrm{mg} \mathrm{kg}^{-1}$. The effect of these concentrations on the earthworm reproduction is discussed in detail below.

The normal range of $\mathrm{Cu}$ concentration in earthworm tissues can be determined through the use of biomarkers of the stress induced by this element. For example, Svendsen and Weeks (1997) used the stability of the lysosomal membrane as a biomarker of sub-cellular stress in the earthworms $E$. andrei exposed to increasing concentrations of $\mathrm{Cu}$. The degree of damage induced by $\mathrm{Cu}$ on the lysosomal membrane depended on its bioaccumulation. No damage to tissue was detected at concentrations of 8 to $25 \mathrm{mg} \mathrm{kg}^{-1}$. Concentrations of 25 to $55 \mathrm{mg} \mathrm{kg}^{-1}$ produced medium damage, while concentrations higher than 55 $\mathrm{mg} \mathrm{kg}{ }^{-1}$ provoked severe damage. Likewise, ScottFordsmand et al. (2000) reported the critical threshold of $50 \mathrm{mg} \mathrm{kg}-1$ of bioaccumulation of $\mathrm{Cu}$ by E. fetida, using the same biomarker of damage to the lysosomal membrane. Similarly, the species Lumbricus rubellus did not show a decrease in the production of cocoons with a $\mathrm{Cu}$ bioaccumulation below the critical threshold of $40 \mathrm{mg}$ $\mathrm{kg}^{-1}$ (Ma, 2005).

In the present study, the bioaccumulation of $23 \mathrm{mg} \mathrm{Cu}$ $\mathrm{kg}^{-1}$ in the earthworms present in the control soil can be considered as normal, in accordance with Svendsen and Weeks (1997). A higher bioaccumulation of $\mathrm{Cu}$ (in the range of 37 to $64 \mathrm{mg} \mathrm{kg}^{-1}$ ) caused a reduction in cocoon production. Svendsen and Weeks (1997) proposed that earthworms can present individual differences in the efficiency of excreting assimilated $\mathrm{Cu}$. Consequently, bioaccumulation of $\mathrm{Cu}$ is not a good biomarker of stress induced by this element, as is reflected in the low regression coefficient $\left(\mathrm{R}^{2}=0.37, \mathrm{P}<0.05\right)$ between the parameters of reproduction and bioaccumulation.

\section{CONCLUSIONS}

The majority of the studied soils in the Aconcagua River basin in Central Chile presented toxic effects on earthworms, inhibiting the production of cocoons and juveniles.

The regression analysis ruled out any evident effects of $\mathrm{Pb}, \mathrm{Zn}$, and As on the response of earthworms.

The observed effects on earthworm reproduction are mainly due to $\mathrm{Cu}$ and $\mathrm{OM}$, explaining $70 \%$ of the variance.

Reproduction of earthworms is not determined solely by $\mathrm{Cu}$, but also by $\mathrm{OM}$. It is necessary to know $\mathrm{OM}$ concentrations to correctly predict the response of macrofauna in soils contaminated by $\mathrm{Cu}$.

\section{ACKNOWLEDGEMENTS}

This study was funded by FONDECYT project 1050403. The authors are grateful to Marco Cisternas (Pontificia Universidad Católica de Valparaíso) for helpful comments.

\section{RESUMEN}

Materia orgánica reduce la toxicidad del cobre para la lombriz Eisenia fetida en suelos de áreas mineras en Chile Central. La cuenca del Río Aconcagua (Chile Central) es una de las más importantes áreas agrícolas en el país. Por otro lado, varias industrias de la minería de cobre $(\mathrm{Cu})$ se encuentran ubicadas en esta cuenca. El objetivo del estudio fue determinar la toxicidad de $\mathrm{Cu}$ para la lombriz Eisenia fetida (Savigny 1826) en los suelos agrícolas de la cuenca. Se determinó la producción de capullos y juveniles de la lombriz en suelos estudiados. Los suelos se diferenciaron por las concentraciones de materia orgánica (MO, rango 2-6\%), pH (rango 7,3-8,3), textura (entre arenoso franca y franco arcillosa) y concentraciones totales de $\mathrm{Cu}$ (rango 230-960 $\mathrm{mg} \mathrm{kg}^{-1}$ ). Las concentraciones de $\mathrm{Cu}$ y $\mathrm{MO}$ en los suelos fueron las variables que determinaron la respuesta biológica de las lombrices. En contraste, $\mathrm{pH}$ y textura no afectaron a esta respuesta. La producción de capullos y juveniles disminuyó considerablemente en suelos con altas concentraciones de $\mathrm{Cu}(>500 \mathrm{mg}$ $\mathrm{kg}^{-1}$ ), independientemente de las concentraciones de MO. La producción de capullos disminuyó en suelos con concentraciones de $\mathrm{Cu}$ inferiores a $500 \mathrm{mg} \mathrm{kg}^{-1}$ cuando las concentraciones de $\mathrm{MO}$ fueron inferiores a 3,5\%. Por el contrario, la producción de capullos no varió cuando la concentración de MO fue superior a 3,5\%. El mismo efecto de MO fue reconocido sobre la producción de juveniles. En este caso, el umbral crítico de la concentración de MO fue de $2,5 \%$. Se concluye la importancia de considerar las concentraciones de MO para predecir las respuestas biológicas de lombrices en estos suelos.

Palabras clave: Eisenia fetida, Río Aconcagua, evaluación del riesgo ecológico, minería de $\mathrm{Cu}$, elementos traza.

\section{LITERATURE CITED}

Davies, N.A., M.E. Hodson, and S. Black. 2003. Is the OECD acute worm toxicity test environmentally relevant? The effect of mineral form on calculated lead toxicity. Environ. Pollut. 121:49-54. 
De Gregori, I., E. Fuentes, M. Rojas, H. Pinochet, and M. Potin-Gautier. 2003. Monitoring of copper, arsenic and antimony levels in agricultural soils impacted and non-impacted by mining activities, from three regions in Chile. J. Environ. Monitor. 5:287-295.

Ginocchio, R., G. Carvallo, I. Toro, E. Bustamante, Y. Silva, and N. Sepulveda. 2004. Micro-spatial variation of soil metal pollution and plant recruitment near a copper smelter in Central Chile. Environ. Pollut. 127:343-352.

González, I., V. Muena, M. Cisternas, and A. Neaman. 2008. Acumulación de cobre en una comunidad vegetal afectada por contaminación minera en el valle de Puchuncaví, Chile Central. Rev. Chil. Hist. Nat. 81:279-291.

Hund-Rinke, K., M. Lindemann, and M. Simon. 2005. Experiences with novel approaches in earthworm testing alternatives. J. Soils Sediments 5:233-239.

Hund-Rinke, K., and H. Wiechering. 2001. Earthworm avoidance test for soil assessments. An alternative for acute and reproductive tests. J. Soils Sediments 1:1520.

Kabata-Pendias, A. 2004. Soil-plant transfer of trace elements: An environmental issue. Geoderma 122:143-149.

Kennette, D., W. Hendershot, A. Tomlin, and S. Sauvé. 2002. Uptake of trace metals by the earthworm Lumbricus terrestris L. in urban contaminated soil. Appl. Soil Ecol. 19:191-198.

Ma, W. 2005. Critical body residues (CBRs) for ecotoxicological soil quality assessment: copper in earthwors. Soil Biol. Biochem. 37:561-568.

Maxwell, J. 1968. Rock and mineral analysis. 584 p. Pergamon Press, Oxford, UK.

McBride, M., S. Sauvé, and W. Hendershot. 1997. Solubility control of $\mathrm{Cu}, \mathrm{Zn}, \mathrm{Cd}$ and $\mathrm{Pb}$ in contaminated soils. Eur. J. Soil Sci. 48:337-346.

Nahmani, J., M.E. Hodson, and S. Black. 2007a. Effects of metals on life cycle parameters of the earthworm Eisenia fetida exposed to field-contaminated, metalpolluted soils. Environ. Pollut. 149:44-58.

Nahmani, J., M.E. Hodson, and S. Black. 2007b. A review of studies performed to assess metal uptake by earthworms. Environ. Pollut. 145:402-424.

NRC. 2003. Bioavailability of contaminants in soils and sediments: Processes, tools and applications. 420 p. Commission on Bioavailability of Contaminants in Soils and Sediments. National Academy Press, Washington, D.C., USA.

OECD. 2000. Draft guideline for the testing of chemicals. 17 p. Earthworm reproduction test (Eisenia fetida/ andrei). Organization for Economic Cooperation and Development (OECD), Paris, France.
Posthuma, L., R. Baerselman, R.P.M. Van Veen, and E.M. Dirven-Van Breemen. 1997. Single and joint toxic effects of copper and zinc on reproduction of Enchytraeus crypticus in relation to sorption of metals in soils. Ecotox. Environ. Safe. 38:108-121.

Rachou, J., C. Gagnon, and S. Sauvé. 2007a. Use of an ion-selective electrode for free copper measurements in low salinity and low ionic strength matrices. Environ. Chem. 4:90-97.

Rachou, J., W. Hendershot, and S. Sauvé. 2007b. Soil organic matter impacts upon fluxes of cadmium in soils measured using diffusive gradients in thin films. Commun. Soil. Sci. Plant Anal. 38:1619-1636.

Sadzawka, A., M.A. Carrasco, R. Grez, G. Mora, H. Flores, y A. Neaman. 2006. Métodos de análisis recomendados para los suelos de Chile. Serie actas INIA $\mathrm{N}^{\circ}$ 34. 164 p. Instituto de Investigaciones Agropecuarias, Santiago, Chile.

Sauvé, S., A. Dumestre, M. McBride, and W. Hendershot. 1998. Derivation of soil quality criteria using predicted chemical speciation of $\mathrm{Pb}^{2+}$ and $\mathrm{Cu}^{2+}$. Environ. Toxicol. Chem. 17:1481-1489.

Sauvé, S., M.B. McBride, W.A. Norvell, W.H., and Hendershot. 1997. Copper solubility and speciation of in situ contaminated soils: Effects of copper level, $\mathrm{pH}$ and organic matter. Water Air Soil Pollut. 100:133149.

Scott-Fordsmand, J., J. Weeks, and S. Hopkin. 2000. Importance of the contamination history for understanding toxicity of copper to earthworm Eisenia fetida (Oligochaeta: Anelida), using neutralred retention assay. Environ. Toxicol. Chem. 19:17741780 .

Sheldrick, B.H., and C. Wang. 1993. Soil sampling and methods of analysis. p. 499-511. In M. Carter (ed.) Particle size distribution. Canadian Society of Soil Science, Lewis Publishers, Boca Raton, Florida, USA.

Slimak, K.M. 1997. Avoidance response as a sublethal effect of pesticides on Lumbricus terrestris (Oligochaeta). Soil Biol. Biochem. 29:713-715.

Spurgeon, D., and S. Hopkin. 1995. Extrapolation of laboratory based OECD earthworm test to metalcontaminated field sites. Ecotoxicology 4:190-205.

Spurgeon, D., and S. Hopkin. 1996. Effects of metalcontaminated soils on the growth, sexual development, and cocoon production of the earthworm Eisenia fetida, with particular reference to zinc. Ecotox. Environ. Safe. 35:86-95.

Spurgeon, D.J., and S.P. Hopkin. 1999. Comparisons of metal accumulation and excretion kinetics in earthworms (Eisenia fetida) exposed to contaminated field and laboratory soils. Appl. Soil Ecol. 11:227-243. 
Spurgeon, D., M. Weeks, and J. Van Gestel. 2003. A summary of eleven years progress in earthworm ecotoxicology. Pedobiologia 47:588-606.

Svendsen, C., and J.M. Weeks, 1997. Relevance and applicability of a simple earthworm biomarker of copper exposure. I. Links to ecotoxicological effects in a laboratory study with Eisenia andrei. Ecotox. Environ. Safe. 36:72-79.
Thakali, S., H. Allen, D. Di Toro, A. Ponizovsky, C. Rooney, F.J.Zhao, and S.P. McGrath. 2006. A terrestrial biotic ligand model. 1. Development and application to $\mathrm{Cu}$ and $\mathrm{Ni}$ toxicities to barley root elongation in soils. Environ. Sci. Technol. 40:7085-7093. 